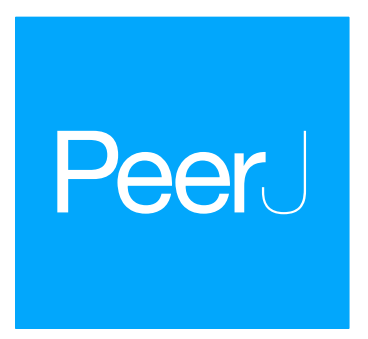

Submitted 13 September 2016

Accepted 29 July 2017

Published 18 August 2017

Corresponding author

Joshua Louis Bonesso,

joshua.bonesso@qut.edu.au

Academic editor

Mauricio Rodriguez-Lanetty

Additional Information and Declarations can be found on page 15

DOI 10.7717/peerj.3719

Copyright

2017 Bonesso et al.

Distributed under

Creative Commons CC-BY 4.0

OPEN ACCESS

\section{Exposure to elevated sea-surface temperatures below the bleaching threshold impairs coral recovery and regeneration following injury}

\author{
Joshua Louis Bonesso ${ }^{1}$, William Leggat ${ }^{1,2}$ and Tracy Danielle Ainsworth ${ }^{2}$ \\ ${ }^{1}$ College of Public Health, Medical and Veterinary Sciences, James Cook University, Townsville, Australia \\ ${ }^{2}$ ARC Centre of Excellence for Coral Reef Studies, James Cook University, Townsville, Australia
}

\section{ABSTRACT}

Elevated sea surface temperatures (SSTs) are linked to an increase in the frequency and severity of bleaching events due to temperatures exceeding corals' upper thermal limits. The temperatures at which a breakdown of the coral-Symbiodinium endosymbiosis (coral bleaching) occurs are referred to as the upper thermal limits for the coral species. This breakdown of the endosymbiosis results in a reduction of corals' nutritional uptake, growth, and tissue integrity. Periods of elevated sea surface temperature, thermal stress and coral bleaching are also linked to increased disease susceptibility and an increased frequency of storms which cause injury and physical damage to corals. Herein we aimed to determine the capacity of corals to regenerate and recover from injuries (removal of apical tips) sustained during periods of elevated sea surface temperatures which result in coral stress responses, but which do not result in coral bleaching (i.e., sub-bleaching thermal stress events). In this study, exposure of the species Acropora aspera to an elevated SST of $32^{\circ} \mathrm{C}\left(2{ }^{\circ} \mathrm{C}\right.$ below the bleaching threshold, $34^{\circ} \mathrm{C}$ ) was found to result in reduced fluorescence of green fluorescent protein (GFP), reduced skeletal calcification and a lack of branch regrowth at the site of injury, compared to corals maintained under ambient SST conditions $\left(26^{\circ} \mathrm{C}\right)$. Corals maintained under normal, ambient, sea surface temperatures expressed high GFP fluorescence at the injury site, underwent a rapid regeneration of the coral branch apical tip within 12 days of sustaining injury, and showed extensive regrowth of the coral skeleton. Taken together, our results have demonstrated that periods of sustained increased sea surface temperatures, below the corals' bleaching threshold but above long-term summertime averages, impair coral recovery from damage, regardless of the onset or occurrence of coral bleaching.

Subjects Ecology, Genetics, Marine Biology, Climate Change Biology

Keywords Coral reefs, GFP, Heat shock proteins (HSP), Injury, Recovery, Scanning Electron Microscopy (SEM), Temperature stress

\section{INTRODUCTION}

Sea surface temperatures (SSTs) have increased in recent decades and are projected to continue to increase at a rate of, on average, $0.12{ }^{\circ} \mathrm{C}$ per decade (Steig et al., 2009). Elevated SSTs have been shown to severely impede calcification and skeletal deposition 
in reef-building corals (Carricart-Ganivet et al., 2012). Synergistic stressors on coral reefs during periods of increased SSTs are also projected to become increasingly common. For example, storm and disease events are projected to increase in frequency and intensity (Hoegh-Guldberg et al., 2007; Hughes et al., 2003) and predation by crown of thorns starfish is predicted to increase in areas with decreasing water quality (De'arth et al., 2012; Brodie et al., 2005). These events in isolation, and where occurring together, will result in a far greater frequency of stress and injury to reef-building corals. However, the capacity of corals to survive and recover is dependent on their capacity to successfully repair and/or regenerate lost tissue and re-grow damaged branches (Kramarsky-Winter \& Loya, 2000). This reformation of both skeleton and tissue at lesion sites is essential for colony survival, growth, reproduction and the prevention of disease (Oren, Benayahu \& Loya, 1997; Van de Water et al., 2015a; Van de Water et al., 2015b).

Corals produce fluorescent proteins (FPs) (Dove, Hoegh-Guldberg \& Ranganathan, 2001) which play integral roles in photoprotection (Salih et al., 2000), photosynthetic enhancement in low-light environments, antioxidant enhancement (Bou-Abdallah, Chasteen \& Lesser, 2006; Palmer, Modi \& Mydlarz, 2009), camouflage (Matz, Marshall \& Vorobyev, 2006), regulation of the coral-Symbiodinium symbiosis (Dove et al., 2008; Field et al., 2006) and the coral innate immune response (Palmer, Modi \& Mydlarz, 2009; D’Angelo et al., 2012). A principle role of Green Fluorescent Proteins (GFPs), photoprotection, regulates the light environment of the coral host tissue and protects the photosynthetic machinery of their endosymbionts from high irradiance (Salih et al., 2000; Schlichter, Weber $\&$ Fricke, 1985). In reef-building corals, GFP concentration has been found to change reversibly with light intensity, increasing in high-light corals and decreasing in medium to low-light corals (Roth et al., 2010). In fact, GFP concentration has been correlated with growth rates and light exposure, with high-light corals exhibiting faster growth rates and fluorescence than low light corals (Roth et al., 2010; Roth et al., 2010). Under high light conditions, GFPs dissipate excess energy and reflect light (Salih et al., 2000). Increased expression of GFP-like proteins can be found around corals' growth zones where symbiont density is lowest, including the apical polyps, upper radial corallites, edges of healthy coral colonies and in areas of high or direct light exposure (D'Angelo et al., 2012). Here, GFPs have been hypothesised to reflect and scatter harmful and potentially damaging energy away from the endosymbionts (Salih et al., 2000; Schlichter, Weber \& Fricke, 1985). Coral tissue compromised by injury, infection and the increased abundance of Reactive Oxygen Species (ROS) have altered GFP fluorescence and expression (Palmer, Modi \& Mydlarz, 2009). For example, an up-regulation of GFP at the site of injured or compromised tissue functions as an antioxidant and scavenger of harmful oxygen radicals (e.g., $\mathrm{H}_{2} \mathrm{O}_{2}, \mathrm{O}_{2}^{-}$and $\mathrm{OH}^{-}$) present at the wound site (Palmer, Modi \& Mydlarz, 2009; Palmer, Roth \& Gates, 2009).

Furthermore, specific GFP-like proteins and proliferating cell nuclear antigen growth markers have been found to show upregulation in growing branches and disturbed parts of colonies. This has been found to be important in the immune and repair response of reef-building corals following injury (D'Angelo et al., 2012). Studies have also shown a decrease in both concentration and expression of GFPs when corals are exposed to thermal stress and undergo bleaching (Dove, 2004; Smith-Keune \& Dove, 2008; Desalvo 
et al., 2008). Under experimental conditions, rapid reduction in GFP concentration has been reported in Montipora monastriata, Acropora yongei, Acropora millepora and Acropora aspera after exposure to thermal stress (Smith-Keune \& Dove, 2008) and a result of decreased symbiont densities (Roth \& Deheyn, 2013). As a result, thermal stress has been postulated to overwhelm the photo-protective mechanisms leading to increased sensitivity to photo-damage (Roth \& Deheyn, 2013).

Regeneration, or the renewal or repair of cells, tissues and organs, is widely distributed yet highly variable among metazoans (Alvarado \& Tsonis, 2006; Sanchez-Alvarado, 2000; Somorjai et al., 2012). Colonial invertebrates including corals, have the capacity to regenerate entire organisms from tissue fragments, dissociated tissues and even reaggregated cells (Bosch, 2007; Gierer et al., 1972; Morgan, 1898). Regeneration is classified into two general categories according to the following criteria: (1) regeneration in the absence of cell proliferation and (2) regeneration mediated by cell proliferation (SanchezAlvarado, 2000). The first, coined morphallaxis is most common in invertebrates, involving the renewal of missing body parts through the remodelling of pre-existing cells. Although cell differentiation is active, the result is a complete individual derived entirely from the reorganisation or exchange of cells from the original organism (Gierer et al., 1972; Chera et al., 2009). Hydra regeneration demonstrates the capacity to regenerate without the creation of new material (Bosch, 2007). When individual (non-colonial) Hydra polyps are severely damaged, the remaining structures are remodelled to regenerate whole body parts including the mouth and tentacles (Agata, Saito \& Nakajima, 2007; Böttger \& Alexandrova, 2007; Passamaneck \& Martindale, 2012). In corals, regeneration following injury has been documented to occur via both morphallaxis, the re-arranging of pre-existing cells in the polyps underlying fine tissue; or epimorphosis, involving a cascade of differentiation and proliferation (Harrison, 1972; Fisher et al., 2007; Meesters, Pauchli \& Bak, 1997). However injury recovery and tissue repair in corals is impeded by thermal stress (Baker, Glynn \& Riegl, 2008; Meesters \& Bak, 1993; Meesters \& Bak, 1994; Baird \& Marshall, 2002). Here we monitored tissue repair, GFP fluorescence, and gene expression patterns in corals for 12 days following injury (removal of apical tips) whilst held under both ambient $\left(26^{\circ} \mathrm{C}\right)$ and sub-bleaching thermal stress $\left(32^{\circ} \mathrm{C}\right)$. In doing so, the study aimed to investigate the impact of sustained exposure to sub-lethal (pre-beaching) temperatures on coral capacity to recover from injury.

\section{MATERIALS AND METHODS}

Large coral colony fragments $(n=20)$ of approximately $20 \mathrm{~cm}$ in diameter were randomly sampled (under Great Barrier Reef Marine Park Authority permit number G13/36402.1) from 4 distinct patches of Acropora aspera ( $\tan$ morph) on the Heron Island reef flat $\left(23^{\circ} 26^{\prime} 36.2^{\prime \prime} \mathrm{S} 151^{\circ} 54^{\prime} 43.1^{\prime \prime} \mathrm{E}\right)$ at low tide during March 2014 (Fig. 1), no genotyping was conducted. Sampling was conducted at a depth of $0.3 \mathrm{~m}$, temperature range of $26-32{ }^{\circ} \mathrm{C}$, and a midday light intensity between 300 to $2,200 \mu$ mol quanta $\mathrm{m}^{-2} \mathrm{~s}^{-1}$. Colony fragments were randomly assigned to two 1,000 litre flow-through seawater mesocosms $(<100 \mathrm{~m}$ from the site of collection), 10 colony fragments were assigned to each system, left to 

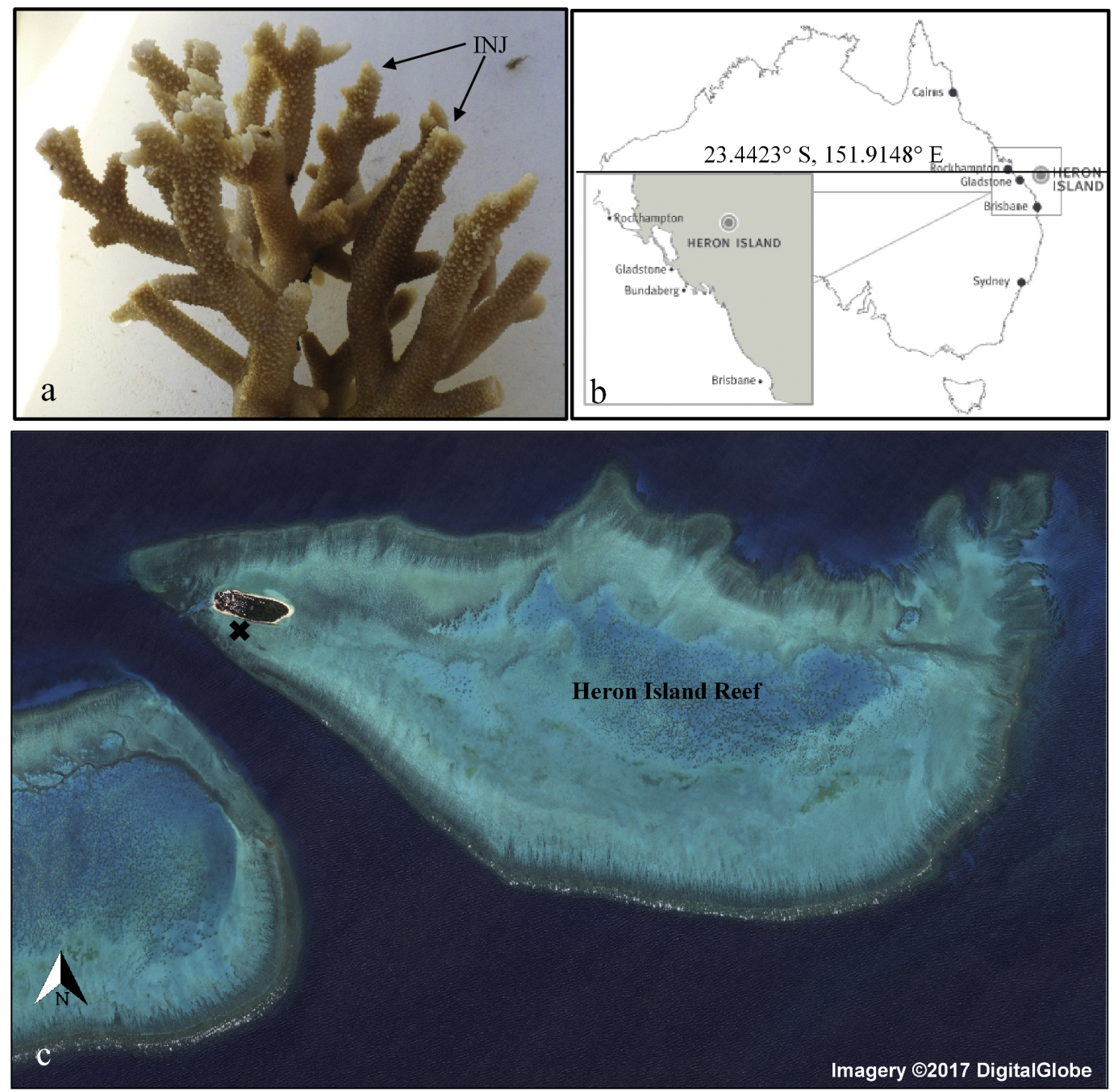

Figure 1 Field site of sample collection of $A$. aspera. Experimental species A. aspera following collection and removal of apical tips on $50 \%$ of colony branches (A), location of study site, Heron Island (B) and map of Heron Island reef from which experimental coral colonies were collected (X) (C) Map Data: Google Maps, DigitalGlobe.

acclimate for 7 days with flow-through seawater sourced directly from the adjacent reef flat at a high turnover rate, and monitored for recovery. Water in-flow and circulation was identical in the mesocosms and monitored throughout the day for the duration of the experimental period. All corals recovered from fragmentation, corals were observed to be feeding and damage points from collection fully healed during the acclimation, resulting in 20 healthy coral colonies to be used for experimental purposes. To mimic expected reef flat light and temperature regimes, both mesocosms were positioned in full sunlight with no direct shading from adjacent structures. Coral colony fragments were also positioned 20 $\mathrm{cm}$ apart from each other, and internal pumps were used to provide sufficient flow within and around the coral colony fragments. 
Two days prior to the end of acclimation, the branches of half the colony colonies in each mesocosm ( $n=5$ coral colony fragment colonies) were injured by having apical tips removed ( $\sim 3 \mathrm{~cm}$ of the apical region) and the remaining five colonies had their tips left intact (Fig. 1). The corals where maintained in ambient conditions for two days to allow wound healing to initiate and corals were monitored for health throughout this period. This design was applied to provide a control baseline comparison of molecular regulation of heat-shock responses between the two mescosms ( $n, 10$ colonies) without the application of sub-lethal thermal stress, and allow for within treatment controls to compare coal recovery under the two thermal regimes. Following the acclimation period one mesocosm was maintained at ambient inflow seawater conditions of $26^{\circ} \mathrm{C}$ while the other mesocosm had incoming seawater increased to $32^{\circ} \mathrm{C}$ (sub-bleaching) during daylight hours over a 12-day period.

Coral colonies showed no visible signs of paling or mucous sloughing when exposed to daily peak temperatures of sub-bleaching $32^{\circ} \mathrm{C}$ ( 2 degrees below the bleaching threshold of $34^{\circ} \mathrm{C}$ for A. aspera (Ainsworth et al., 2016)) with changes in tissue pigmentation monitored twice daily and compared to coral health check colour cards. To replicate natural reef temperature conditions, aquarium heaters in the temperature treatment mesocosm $\left(32^{\circ} \mathrm{C}\right)$ were switched off at $1,900 \mathrm{~h}$ and switched on from $0,700 \mathrm{~h}$ each day for a duration of $12 \mathrm{~h}$. Seawater temperature was recorded using Odyssey temperature loggers (Christchurch, New Zealand) every two minutes. Light levels in both systems were monitored every 10 min with Odyssey Photosynthetic Active Radiation (PAR) recorders (Dataflow Systems Limited, Christchurch, New Zealand), ranging between 700-1,500 $\mu$ mol quanta $\mathrm{m}^{-2} \mathrm{~s}^{-1}$.

On days 2, 4, 6, 8, 10 and 12 following removal of the apical tips, 4 branches from each coral colony fragment were randomly sampled at mid-day $(1200 \mathrm{~h})$ from each of the two treatments. Coral branches ( $n=2$ of 4 ) were fixed with $4 \%$ paraformaldehyde (PFA) and $3 \times$ Phosphate Buffer Saline (PBS) overnight, then transferred and stored in $3 \times$ PBS at $4{ }^{\circ} \mathrm{C}$. The remaining coral branches $(n=2$ of 4$)$ were also immediately snap-frozen in liquid nitrogen $\left(\mathrm{LN}_{2}\right)$ and stored at $-80^{\circ} \mathrm{C}$. Coral branches snap frozen in liquid nitrogen were crushed using a hydraulic press and homogenised to a fine powder in a mortar chilled with liquid nitrogen under RNase free conditions. Samples were then stored at $-80{ }^{\circ} \mathrm{C}$ for mRNA purification using the Dynabeads ${ }^{\circledR}$ mRNA DIRECT ${ }^{\mathrm{TM}}$ Kit (Ambion, Foster City, CA, USA) and DNase/cDNA synthesis. Messenger RNA was isolated from approximately $150 \mathrm{mg}$ of crushed sample from injured $(n=120)$ and non-injured $(n=120)$ coral branches using the Dynabeads ${ }^{\circledR}$ mRNA DIRECT ${ }^{\mathrm{TM}}$ Kit (Ambion, Foster City, CA, USA) (as per manufactures instructions). Isolated mRNA was quantified spectrophotometrically using a NanoDrop-1000 (NanoDrop Technologies, Wilmington, DE, USA). Genomic DNA contamination was removed from $0.1 \mu \mathrm{g}$ of mRNA via a DNase digest treatment using the RQ1 RNase-Free DNase (Promega, Madison, WI, USA). Complementary DNA (cDNA) was synthesised from DNase-treated mRNA for use in quantitative real-timePCR (qRT-PCR). Approximately $100 \mathrm{ng}$ of mRNA was reverse transcribed using the SuperScript ${ }^{\mathrm{TM}}$ III First-Strand Synthesis (SSIII) SuperMix for qRT-PCR (Invitrogen), according to manufacturer's instructions, with oligo (dT) primers. 


\begin{tabular}{lll}
\hline $\begin{array}{l}\text { Table } 1 \text { Oligonucleotide sequences of target and housekeeping genes. Oligonucleotide primer } \\
\text { sequences of target and housekeeping genes for RT-qPCR of } \text { A. aspera. }\end{array}$ & \\
Gene name & Oligonucleotide primer sequence $\left(\mathbf{5}^{\prime}-\mathbf{3}^{\prime}\right)$ & Cited source \\
\hline $\begin{array}{l}\text { Target genes } \\
\text { HSP70 }\end{array}$ & $\begin{array}{l}\mathrm{F}_{1} \text { :AGGAGACCGCTGAGGCATACTTG } \\
R_{1} \text { :CTTGGTGGCCTGACGCTGAGAATC }\end{array}$ & Ogawa et al. (2013) \\
HSP90 & $\mathrm{F}_{1}$ :ATTCCGAGGATCTGCCACTGA & \\
& $\mathrm{R}_{1}$ :TCTCTGCGATCTCTGCGAACAT & Ogawa et al. (2013) \\
Catalase & $\mathrm{F}_{1}$ :GCAAAGTAGTTGGACGCGTTAC & \\
& $\mathrm{R}_{1}$ :GGAATCCTTTCGACCTCACTAAG & Seneca et al. (2010) and \\
Housekeeping genes & & Ainsworth et al. (2016) \\
Ctg1913 & $\mathrm{F}_{1}$ :GATTTAACCACCGGCAGTGT & \\
Ado & $\mathrm{R}_{1}$ :ATGGTAGGGAGGAGGCTGTT & Ogawa et al. (2013) and \\
& $\mathrm{F}_{1}$ :AAGAAGACAAACATCAAGCCTCA & Ainsworth et al. (2016) \\
& $\mathrm{R}_{1}$ :CACATCCAAGGTTCACAAGACG & Ogawa et al. (2013) \\
\hline
\end{tabular}

Quantitative real-time PCR was performed using a Rotor-Gene ${ }^{\mathrm{TM}} 6000$ (Corbett Life Sciences, New South Wales, Australia) robot and a CAS-1200 robotic liquid handling system (Corbet Robotics, Australia). A final volume of $15 \mu$ l was analysed in the PCR, containing $7.5 \mu \mathrm{l}$ of GoTaq ${ }^{\circledR}$ qPCR Master Mix (Promega, Madison, WI, USA), $3.5 \mu$ l of gene specific primers and $4 \mu \mathrm{l}$ of dilute cDNA template. Quantitative PCR was performed under the following conditions: a 1 cycle hold-start activation at $95^{\circ} \mathrm{C}$ for $2 \mathrm{~min}$, followed by 40 cycles of $15 \mathrm{~s}$ at $95^{\circ} \mathrm{C}$ and $60 \mathrm{~s}$ at $60{ }^{\circ} \mathrm{C}$, with a melt stage between $55^{\circ} \mathrm{C}$ and $95{ }^{\circ} \mathrm{C}$ with a temperature increase of $1{ }^{\circ} \mathrm{C}$ every $5 \mathrm{~s}$. General stress response genes were quantified to confirm corals' were undergoing thermal stress responses (heat shock protein 70 (HSP70), heat shock 90 (HSP90) and Catalase). In addition to the genes of interest, Adohcyase (Ado) and Ctg1913 were used as coral housekeeping genes (HKGs) (Table 1). Each Rotor-Disc ${ }^{\mathrm{TM}} 100$ (Qiagen, Hilden, Germany) included three technical replicates for 10 biological samples with two template/housekeeping genes. Technical replicates were automatically averaged when CT values were within 1 CT. In the few cases were this was not the case amplification curves of the replicates were examined manually, and replicates removed where amplification did not occur. Samples were repeated if filtered technical replicates were not with one CT value. Non-template controls for all runs were performed in triplicate.

Template cDNA dilution series were prepared to optimize quantification accuracy. Serial dilutions between $1 / 5$ and 1/80 were performed on a composite of cDNA randomly selected from a variety of thermal regimes over the course of the experiment. These dilutions were used to construct standard curves for the three target genes, HSP70, HSP90 and Catalase; and two housekeeping genes, Ado and Ctg1913. For analysis, cDNA was diluted 1/10 prior to use as a template in qRT-PCR analysis. Standard curves for each gene were imported into qBASE plus 2.5 software (Biogazelle; http://www.biogazelle.com/products/qbasePLUS) for CT value normalisation by calculating the geometric mean of the housekeeping genes. Relative expression analysis were then performed using qBASE. Statistics software package SPSS (SPSS Statistics v 22.0, IBM, Armonk, North Castle, NY, USA) was used for all 
statistical analyses. Significant differences in the relative expression of heat shock protein, HSP70 and HSP90; and antioxidant genes, Catalase, were determined using a generalised linear model. 'Injury' and 'temperature' were both considered as single factors with two levels. Factor 'day' was accounted as a repeated measure. For significantly different data the sequential Bonferroni post-hoc least significant difference (LSD) test was performed to adjust for type I error.

PFA fixed coral tips were viewed and photographed under an Olympus stereoscopic microscope (Olympus SZX16 ${ }^{\circledR}$, SDF PLAPO; Olympus Corporation of America, Center Valley, PA, USA). Photographs of the apical and lateral polyps were taken using a Fujifilm MX-2900ZOOM digital camera, under both visible light and GFP epifluorescence (Excitation wavelength $=460-490 \mathrm{~nm}$; Emission wavelength $=510 \mathrm{~nm}$ ). GFP fluorescence at the injury site was quantified using image analysis software ImageJ by calculating Corrected Total Cell Fluorescence $(\mathrm{CTCF}=$ Integrated Density $-($ Area of selected cells $\times$ Mean Fluorescence of background readings)) (McCloy et al., 2014; Burgess et al., 2010). Following visible and epifluorescence microscopy, the PFA fixed coral tips were then bleached using a 1:1 ratio of $4 \%$ hypochlorite bleach (Brighton Professional) to tap water to remove all biological material, followed by three washes in tap water to remove any residual calcified crystals. The calcified tips were then placed onto aluminium mounts using the plastic conductive carbon cement Leit-C-Plast (ProSciTech, Australia ${ }^{\mathrm{TM}}$ ), and coated in six layers of gold. Samples were viewed and photographed using scanning electron microscopy (SEM) (JOEL, Tokyo, Japan, model JSM5410LV) at $15 \times$ and $5.0 \mathrm{kv}$ magnification to compare topographical differences in apical tip growth under ambient verses temperaturetreated (sub-bleaching) conditions over the 12-day experimental period. Linear extension of the regenerating apical tips was measured from a fixed landmark (centre point on the cut site at the base of the apical tip to the top of the extending apical tip) using ImageJ, with coral branches positioned in the same direction in each image. Repeated measures ANOVAs were performed using SPSS (SPSS Statistics v 22.0, IBM, USA) to compare (1) differences in linear extension $\left(\mathrm{mm} \mathrm{day}^{-1}\right)$ and (2) differences in GFP fluorescence intensity (CTCF) between ambient and temperature stressed treatments.

\section{RESULTS}

\section{Visible and GFP epi-fluorescent response to injury and thermal stress}

The regenerative and wound healing response of experimentally injured A. aspera to the synergistic impacts of thermal stress was documented by a time-series of micrographs of the apical tips of colonies held under temperature stressed and ambient conditions. Examination of colonies with their apical tips removed, revealed significant apical regeneration/healing under ambient summertime seawater conditions $\left(26^{\circ} \mathrm{C}\right)$ (Figs. 2A-2F). More than $50 \%$ of regrowth of the apical tip had occurred by day 8 and complete regrowth of the apical tip was evident by experimental day 12. Epifluorescence examination of apical tips of corals under ambient conditions further revealed that GFP fluorescence was evident at the wound site where the apical tip had been removed and within the reforming apical tip (Figs. 2G-2L). GFP fluorescence measured via the CTCF method 
Day 2
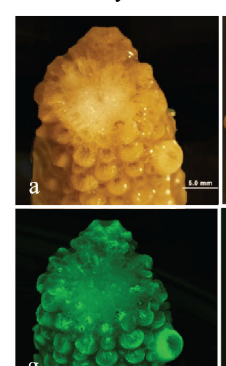

$\mathrm{g}$

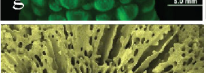

Day 4
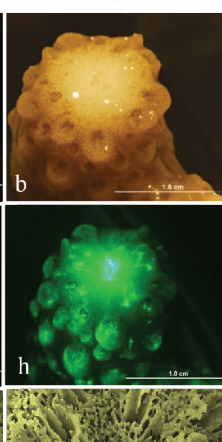

Day 6

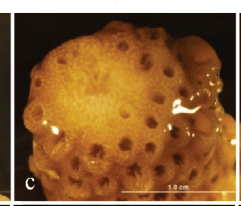

Day 8

Day 10
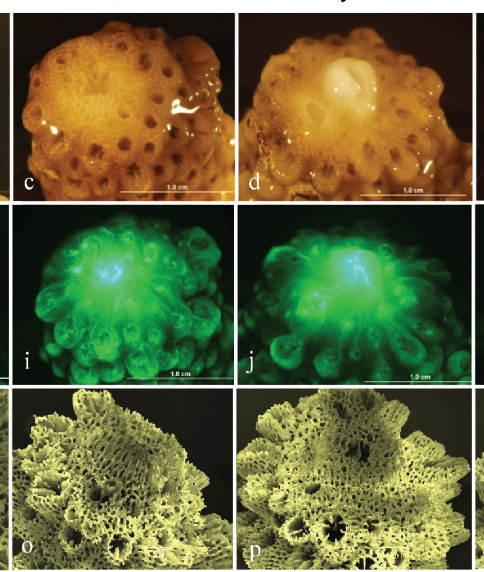

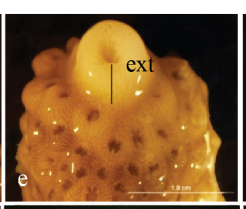

Day 12

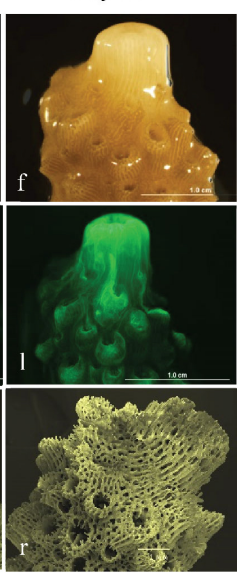

Figure 2 Microscopic examination of apical tip regeneration following exposure to ambient SST conditions. Time series photograph (A-F), epi-floruescence photographs (G-L) and scanning electron micrograph of skeletal structure (M-R) of A. aspera injured corals held under ambient SST conditions $\left(26^{\circ} \mathrm{C}\right)$. Measure of apical tip extension denoted by (ext).

Day 2

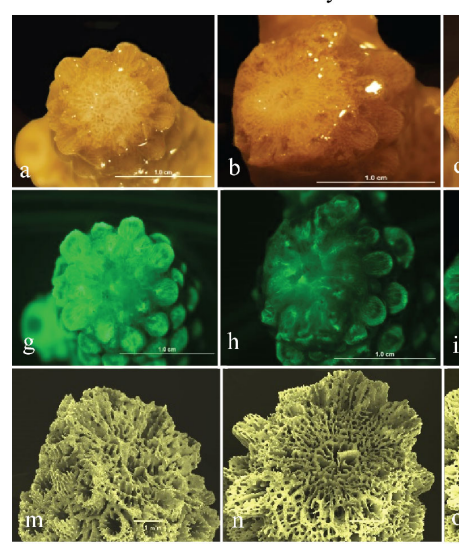

Day 6

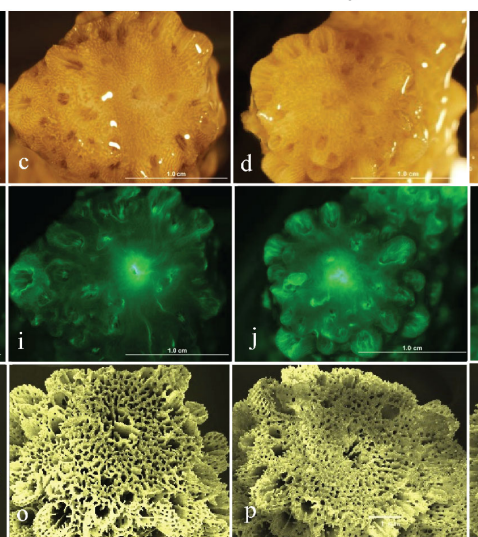

Day 10

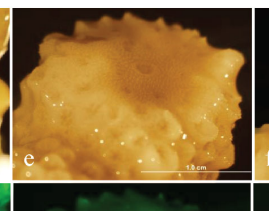

Day 12

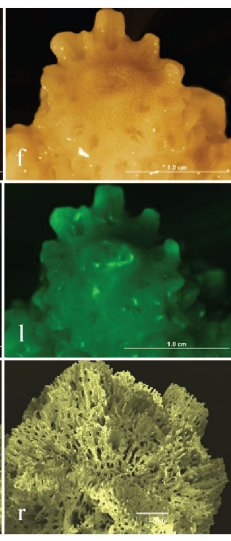

Figure 3 Microscopic examination of apical tip regeneration following exposure to elevated SST conditions. Time series photograph (A-F), epi-floruescence photographs (G-L) and scanning electron micrograph of skeletal structure (M-R) of A. aspera injured corals held under elevated SST conditions $\left(32^{\circ} \mathrm{C}\right)$.

(McCloy et al., 2014; Burgess et al., 2010) was significantly different for corals exposed to ambient and temperature stressed conditions (Wilks' Lambda $=0.42, F_{1,5}=6.8, p<0.05$ ). GFP fluorescence increased during apical tip regrowth between day $2(\sim 300000 \mathrm{CTCF})$ and 10 ( $\sim 2500000$ CTCF) under ambient seawater conditions and was observed within the newly forming coral apical tip throughout the experimental period. During exposure to sub-bleaching seawater temperature conditions, increased GFP fluorescence was only evident at the central polyp growth channel on the wound site at day $4(\sim 1100000 \mathrm{CTCF})$, $6(\sim 1100000 \mathrm{CTCF})$ and $8(\sim 1000000 \mathrm{CTCF})$ (Figs. 3H-3L) (Fig. 4). 


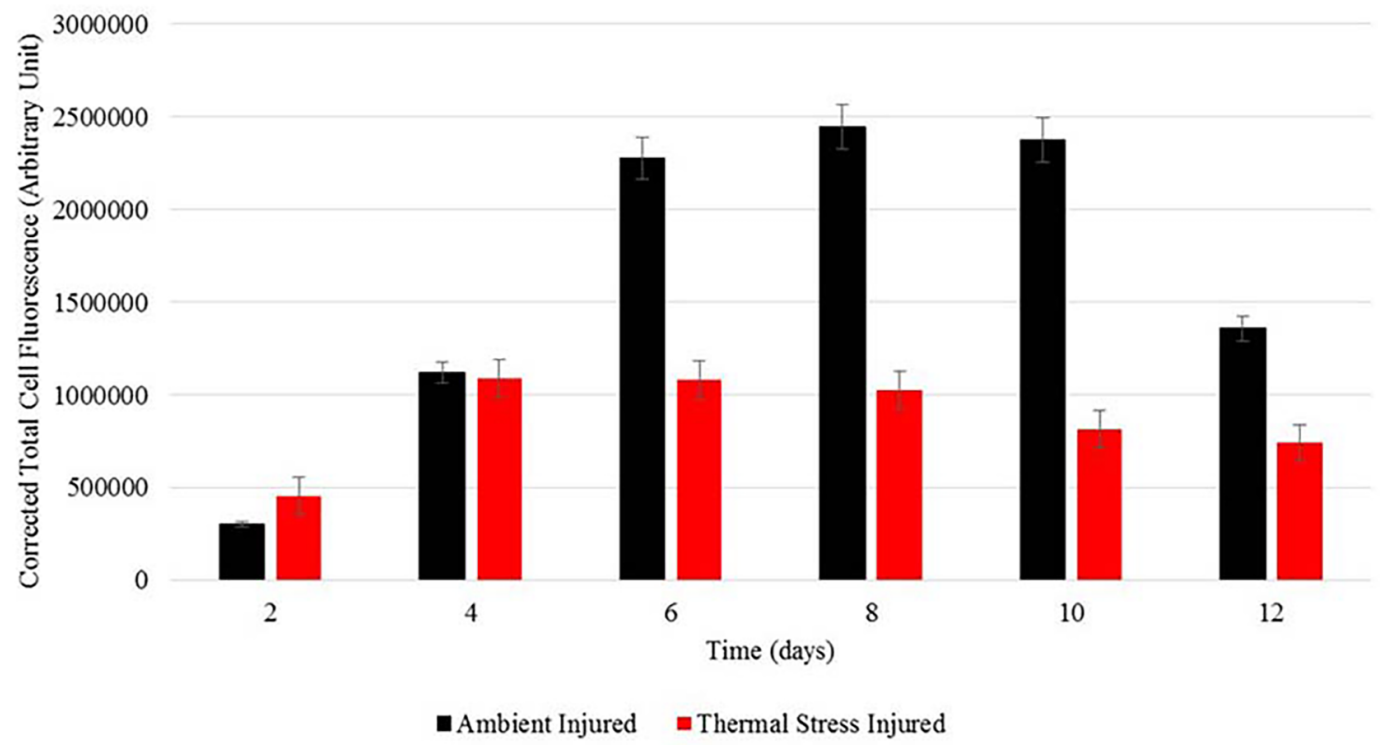

Figure 4 Corrected Total Cell Fluorescence. Average Corrected Total Cell Fluorescence (CTCF) of injury site (i.e., site of apical tip removal) in A. aspera held under ambient $\left(26^{\circ} \mathrm{C}\right)$ and elevated $\left(32^{\circ} \mathrm{C}\right) \mathrm{SST}$ conditions, Mean $= \pm 1$ s.e.

\section{Calcification response to injury and thermal stress}

Scanning electron microscopy was used to examine the effect of sub-bleaching thermal stress on skeletal regeneration of the coral apical tips. Exposure to sub-bleaching conditions $\left(32{ }^{\circ} \mathrm{C}\right)$ had a visible effect on patterns of skeletal regeneration across the 12-day experimental period. Un-injured corals sampled from days 2 and 12 were used as base-line comparisons of intact corallite structure. Skeletal linear extension $\left(\mathrm{mm}\right.$ per day $\left.{ }^{-1}\right)$ of the coral apical tip was significantly different between temperature stressed and ambient seawater conditions (Wilks' Lambda $=0.33, F_{1,5}=9.8, p<0.05$ ) (Fig. 5). During exposure to ambient seawater conditions, $\sim 1.44 \mathrm{~mm}$ extension of the calcium carbonate skeletal was evident by day 6 with complete extension of $\sim 2.2 \mathrm{~mm}$ evident by day 12 . Under exposure to sub-bleaching temperature stress an emergent apical tip was only evident in some samples by day 10 with only $\sim 0.5 \mathrm{~mm}$ extension of the apical tip evident.

\section{Gene expression analyses}

Heat shock protein and catalase regulation were examined in the coral host throughout the experimental period. Both temperature and injury had a significant effect on catalase expression resulting in a down-regulation at day $4(14,069.56$ fold, $p<0.001)$. There was also a significant interaction of temperature and injury at day 4 on catalase expression. Under ambient (control) conditions on this day, there was no significant difference in expression between injured and non-injured corals. Instead, at elevated temperatures, there was a significant difference in expression between injured and non-injured corals (1000.1 fold, $p<0.001$ ) (Fig. 6A). The response of both HSP70 and HSP90 was determined for the coral $A$. aspera over the course of the 12 day experimental period. In the coral host, temperature had a significant effect on HSP70 and HSP90 expression, resulting in a 


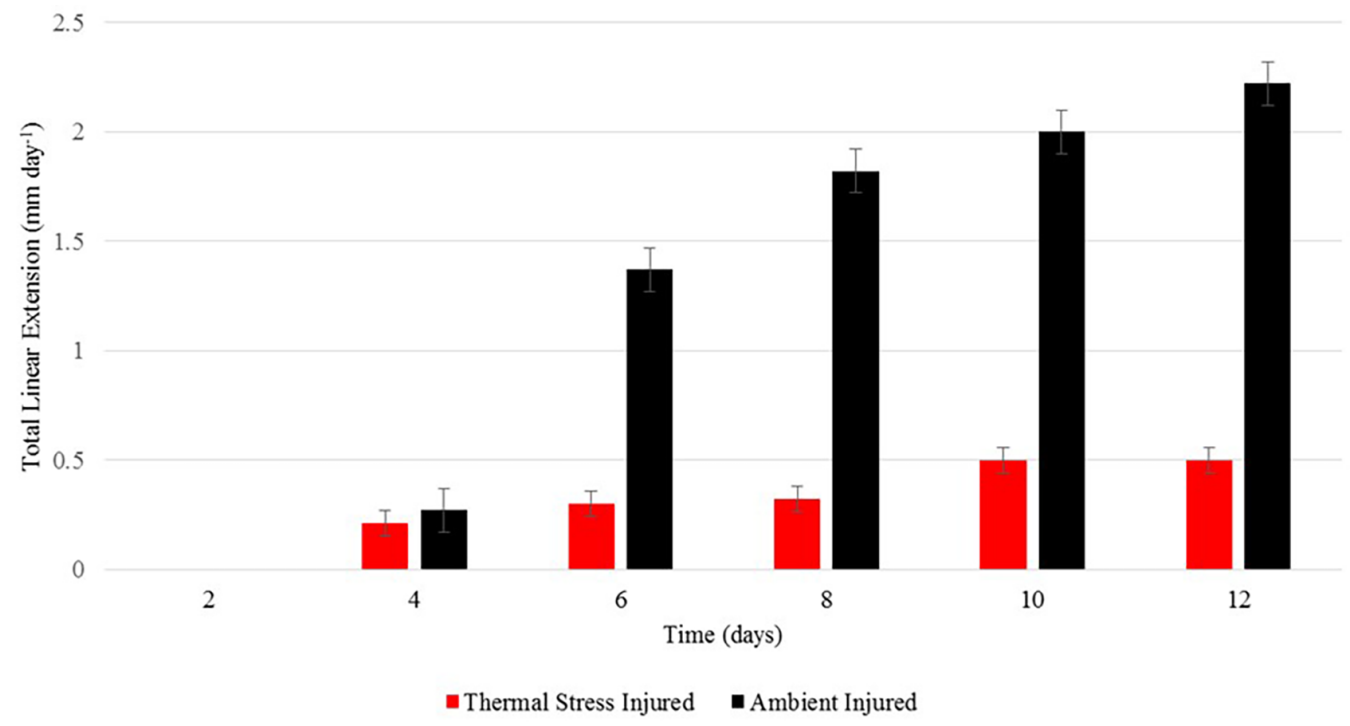

Figure 5 Linear extension rates. Average total linear extension $\left(\mathrm{mm}_{\mathrm{m}}\right.$ per day $\left.{ }^{-1}\right)$ of apical tips in A. aspera held under ambient and elevated SST conditions, Mean $= \pm 1$ s.e.

down-regulation at day 12 (979 fold decrease, $p<0.001 ; 1,676$ fold decrease, $p<0.001$ ). However, there was no significant interaction between temperature and injury on both HSP90 (Fig. 6B) and HSP70 expression (Fig. 6C).

\section{DISCUSSION}

In scleractinian corals injury results in the removal of tissue and/or skeletal from the colony. Injuries are generally categorised based on the amount of tissue lost, including partial or total tissue injuries, and superficial (e.g., scrapings/gross lesions) or extensive (e.g., bump/branch removal) for injuries resulting in functional and morphologic changes in tissue and skeleton (Stafford-Smith, 1993; Hall, 1997). Regeneration/wound healing following extensive injury has been documented to occur in $>74$ days post-injury, and between $24 \mathrm{~h}$ and 80 days following partial injuries (Hall, 1997; Bak, 1983; Meesters \& Bak, 1994; DeFilippo et al., 2016). Here we find the recovery and regeneration of A. aspera to injury (i.e., apical tip removal) was significantly impeded following exposure to subbleaching thermal stress conditions $\left(32^{\circ} \mathrm{C}\right)$ compared to summertime ambient seawater conditions $\left(26^{\circ} \mathrm{C}\right)$. Injured corals showed less than $50 \%$ apical tip regrowth occurring within 12 days post-injury. Previous studies have shown that corals compromised by thermal stress have reduced growth rates (Leder, Szmant \& Swart, 1991) and consequently lower tissue regeneration capacities (Meesters \& Bak, 1993). This is supported by Denis et al. and colleagues (2013) who reported a significant reduction in the regeneration/recovery of superficial lesions on A. muricata nubbins at sites exposed to high fluctuating seawater temperatures ( $\sim 192$ days post-injury) as opposed to sites characterised by stable seawater temperatures ( $\sim 81$ days post-injury). Damaged juvenile colonies of Porites spp. were also found to show impeded regeneration at sub-lethal $29.6^{\circ} \mathrm{C}$ compared to colonies exposed to $26.7^{\circ} \mathrm{C}$ (Edmunds \& Lenihan, 2010). Similarly, comparison of wound healing in naturally 

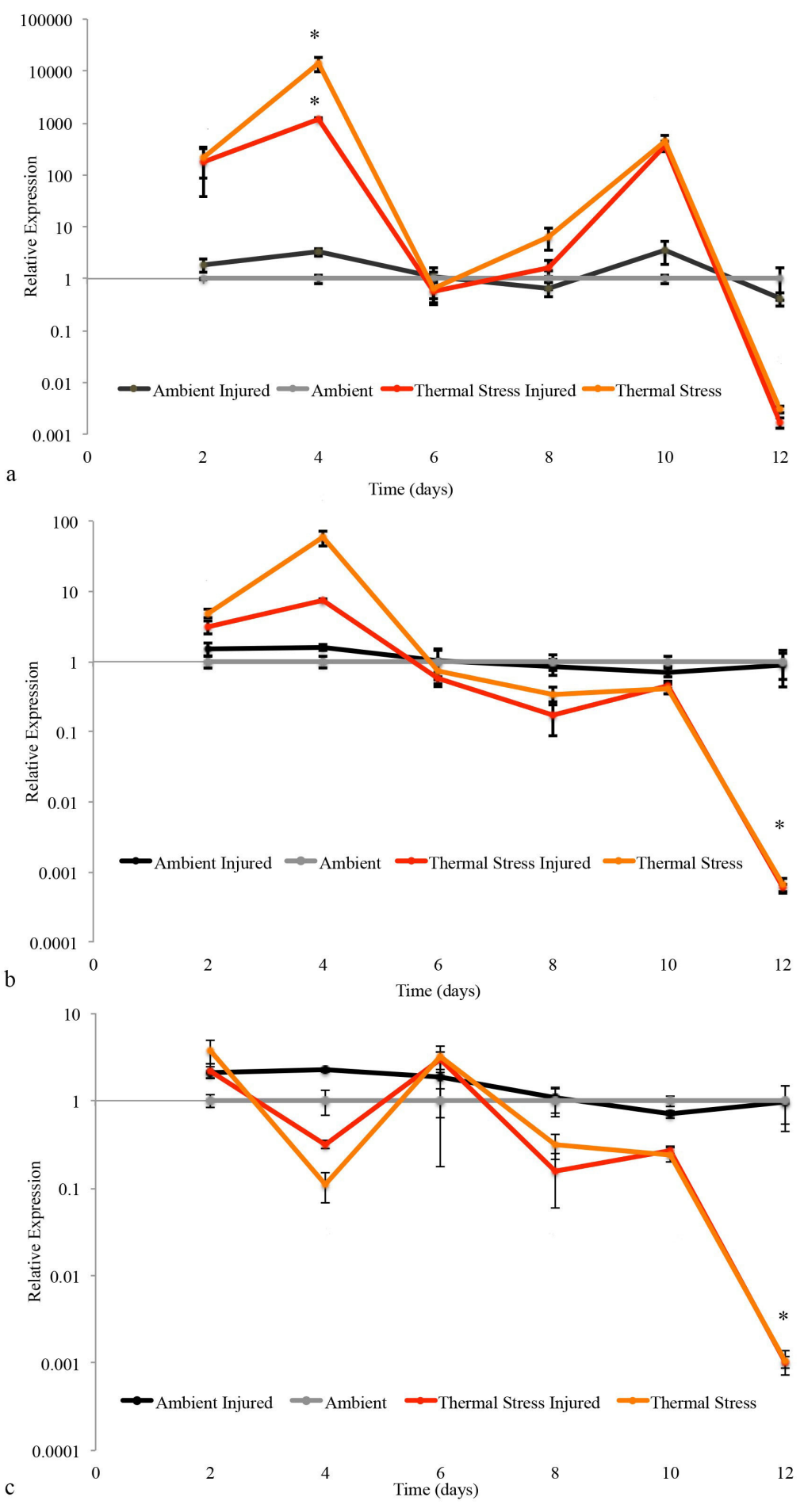

Figure 6 Relative gene expression of target genes. Relative expression of injured and un-injured A. aspera Catalase (A), HSP 90 (B), and HSP 70 (C) in corals held under ambient $\left(26^{\circ} \mathrm{C}\right)$ and elevated $\left(32{ }^{\circ} \mathrm{C}\right)$ SST conditions, Mean $= \pm 1$ s.e. 
non-symbiotic and symbiotic Astrangia poculata found that the presence of Symbiodinium increased wound healing ability (DeFilippo et al., 2016; Burmester et al., 2017). In view of this, our observations suggest that exposure to sub-bleaching thermal stress $\left(32^{\circ} \mathrm{C}\right)$ also impairs the healing capacity of $A$. aspera due to a reduced availability of energetic resources and that the cellular regeneration and repair mechanisms may be compromised by the physical environment and the direct effects of temperature on coral metabolism and growth (as described by Kramarsky-Winter \& Loya, 2000; Jokiel, 2004; Edmunds \& Gates, 2008). Studies with additional mesocosms and temperature conditions could further characterise the dynamics of this synergistic interaction.

\section{Calcification response to injury and thermal stress}

Exposure to sub-bleaching thermal stress $\left(32^{\circ} \mathrm{C}\right)$ had a visible impact on skeletal formation at the coral apical tip, with linear extension only evident in some samples by day 10 compared to full extension being evident by day 12 in corals held in normal, ambient, seawater conditions $\left(26^{\circ} \mathrm{C}\right)$. Calcification and extension rates in corals are significantly greater at the top of colonies (i.e., branch tips) than at the sides (Lough \& Barnes, 2000). When subjected to thermal stress, reef-building corals have been shown to exhibit abnormally reduced extension and calcification rates, and are more susceptible to other stressors including bleaching (Goreau \& Macfarlane, 1990); Meesters \& Bak, 1993; De'ath, Lough \& Fabricius, 2009; Cantin et al., 2010). Previous studies have postulated an increase in calcification rates with increasing temperature up to an optimum and then declining significantly as water temperatures approach $\sim 30^{\circ} \mathrm{C}$, likely the result of increasing levels of thermal stress (Jokiel \& Coles, 1977; Marshall \& Clode, 2004). Our results, in conjunction with what has been reported in previous literature, indicate that exposure of $A$. aspera to synergistic sub-bleaching thermal stress $\left(32^{\circ} \mathrm{C}\right)$ substantially reduces skeletal extension in the coral apical tips. It is also possible that physiological adjustments (i.e., higher rates of heat shock protein production and/or ROS scavenging) could exert energetic costs high enough to subvert calcification (Dandan et al., 2015), thus explaining the reduced calcification and extension in the A. aspera apical tips when subjected to sub-bleaching thermal stress.

\section{GFP epi-fluorescent response to injury and thermal stress}

GFP epi-fluorescence was found to be significantly lower in injured corals under thermally stressed seawater conditions $\left(32^{\circ} \mathrm{C}\right)$, compared to ambient seawater conditions $\left(26^{\circ} \mathrm{C}\right)$. In the current study GFP fluorescence in the apical tips was found to significantly increase between days 4 and 12 following injury under normal ambient seawater conditions $\left(26^{\circ} \mathrm{C}\right)$, but an increase in GFP at the injury site was absent in thermally stressed, injured, corals. Simultaneous exposure to thermal stress and/or solar radiation in shallow tropical waters such as that exposed to A. aspera, is known to cause photoinhibition and increase the production of damaging ROS in Symbiodinium and coral host tissue, and lead to perturbations of the metabolic and cellular processes in Symbiodinium and/or their coral host cells (Smith, Suggett \& Baker, 2005; Bou-Abdallah, Chasteen \& Lesser, 2006) due to the overwhelming of antioxidant defences. In A. aspera, GFP-like homologs are also 
hypothesised to be photo-protective at normal temperatures less than $32{ }^{\circ} \mathrm{C}$ (Dove, 2004). The observed increase in GFP fluorescence may be due to the photo-protection of newly differentiating host tissue from the build-up of harmful ROS elevated in the epithelial and gastrodermal tissue during injury, in addition to the deposition of a newly forming calcium carbonate skeleton. A high concentration of host pigments in this active growth region acts to deflect visible, infra-red light and thermal damage from the coral host tissue surfaces (Bou-Abdallah, Chasteen \& Lesser, 2006; Salih et al., 2000; Kaniewska et al., 2012), however this protection does not occur under temperature regimes which result in thermal stress to the coral.

\section{Antioxidant gene expression}

Endogenous antioxidant enzymes including catalase and superoxide dismutases are a corals first line of defence against the harmful effects of excessive ROS production in Symbiodinium and host tissues. The sensitivity of these enzymes to temperature makes them particularly useful indicators for the onset of thermal stress and bleaching in reef-building corals (Seneca et al., 2010; Merle et al., 2007). In the current study, exposure of $A$. aspera to sub-bleaching thermal stress $\left(32^{\circ} \mathrm{C}\right)$ was characterised by a significant up-regulation in catalase expression at day 4. In corals, up-regulation of catalase is important in limiting the production of highly cytotoxic hydroxyl radicals (Ross et al., 2010). Our findings in A. aspera following thermal stress are consistent with previous studies in various species of adult and juvenile corals, reporting consistent up-regulation within $48 \mathrm{~h}$ following immediate exposure to increased seawater temperatures (Voolstra et al., 2009; Pernice et al., 2011).

Catalase expression was also found to show significant up-regulation at day 4 in response to injury. Coral tissue compromised by injury, exhibit an increased abundance of damaging oxygen radicals, due to increased activity of the melanin-synthesis pathway (Palmer, Modi \& Mydlarz, 2009). This may therefore have resulted in the induction of catalase as a scavenger of ROS at the site of injury, resulting in a significant up-regulation. Further evidence may be drawn from higher metazoan species and plants. Following traumatic brain injury in rats, catalase showed significant upregulation 3 days post-injury in comparison to non-traumatised controls. This was followed by a return to normal expression by day 7 (Goss et al., 1997). Given the findings in A. aspera, peak expression was found at day 4 followed by a drop in expression level at day 6. Findings by Guan, Zhao \& Scandalios (2000) have also reported up-regulation of three catalase homolog genes in response to wounding in immature embryos and leaves of maize, a response to increased levels of endogenous $\mathrm{H}_{2} \mathrm{O}_{2}$ in wounded tissue and leaves. Importantly, a significant temperature stress/injury interaction effect on catalase up-regulation was found only under thermally stressed seawater temperatures. During the coral stress response, the effects from temperature stress, injury and/or infection contribute to elevated ROS in the coral host tissue (Palmer, Modi \& Mydlarz, 2009). Hence, it can be postulated that the combination of sub-bleaching temperature and injury in A. aspera were responsible for an up-regulation in catalase activity in response to overcome the overproduction of damaging ROS at the injured apical tips. 


\section{HSP gene responses}

The role of HSPs as molecular chaperones are to aid in proper protein folding and prevent aggregation at elevated temperature and other stressors (Sørensen, Dahlgaard \& Loeschcke, 2001), and are generally normally up-regulated by organisms under heat stress (Feder \& Hofmann, 1999). It is therefore unusual that no significant up-regulation of HSP70 or HSP90, following exposure to sub-bleaching thermal stress in A. aspera, was observed during this study. Despite this, a significant down-regulation was reported only at day 12. Several studies examining thermal stress in a diversity of coral species have failed to detect an up-regulation in either genes. Desalvo et al. (2008) reported no up-regulation in HSP70 in thermally stressed M. faveolata, while Mayfield et al. (2011) found no differential expression of HSP70 in heat stressed Seriatopera hystrix. Lack of differential expression in the HSPs may have resulted from not sampling earlier enough to capture expressional changes following the induction of thermal stress (Bellantuono et al., 2012). Studies on the effect of heat stress on A.millepora larvae supports this interpretation, with the transcriptional induction of HSP70 and HSP90 detected after only $3 \mathrm{~h}$ (Rodriguez-Lanetty, Harii \& Hoegh-Guldberg, 2009). However, it is important to acknowledge that a rapid induction of HSPs following heat stress has been reported in several coral species including A. grandis, M. faveolata and Goniopora djiboutiensis.

\section{CONCLUSION}

Understanding corals' capacity for recovery, the drivers of a failure to recover from injury, and the underlying mechanisms governing coral regeneration/injury repair, are particularly important given the projected change to coral reefs under future climate change. Mass bleaching events, attributed to increasing SSTs and solar irradiance (e.g., UV and IR), have driven a worldwide decline of $30 \%$ in coral cover (Harrison, Dubinsky \& Stambler, 2011; Hill \& Wilkinson, 2004; Hoegh-Guldberg et al., 2004). Despite this, the underlying molecular and cellular mechanisms controlling regenerative/repair processes under thermal stress have not been thoroughly investigated. In addition, recent work has demonstrated that the coral immune system assists in protecting regenerating tissue from microbial competition (Van de Water et al., 2015a; Van de Water et al., 2015b), which is particularly important considering how microbial populations may shift as climate changes (Ainsworth \& Gates, 2016). This study was the first to demonstrate a synergistic impact of temperature and injury to coral recovery, regrowth and skeletal regeneration in Acroporid corals. In doing so, this study also highlights the need for further research into both synergistic and sub-bleaching stressors to further determine the impact of climate change on coral reef ecosystems.

\section{ACKNOWLEDGEMENTS}

The authors would like to thank Dr Ben Gordon, Dr Jörg Frommlet and Ms Ligia Maria Sousa for sample collection at Heron Island Research Station. We would also like to thank the scientific and technical staff of Heron Island Research Station for assistance in experimental set-up and logistics. JB would also like to cordially thank As/Prof Jennifer Firn, Dr Carmelo Fruciano and Ms Erica Porter, QUT, for proofreading drafts of the manuscript. 


\section{ADDITIONAL INFORMATION AND DECLARATIONS}

\section{Funding}

This work was supported by the Australian Research Council, Discovery Program (grant number DP130101421) awarded to TA \& WL; Australian Research Council, Super Science Program (grant number FS110200046) awarded to TA; and the Australian Research Council, Centre of Excellence for Coral Reef Studies (grant number CE0561435). The funders had no role in study design, data collection and analysis, decision to publish, or preparation of the manuscript.

\section{Grant Disclosures}

The following grant information was disclosed by the authors: Australian Research Council, Discovery Program: DP130101421. Australian Research Council, Super Science Program: FS110200046.

Australian Research Council, Centre of Excellence for Coral Reef Studies: CE0561435.

\section{Competing Interests}

William Leggat and Tracy Ainsworth are Academic Editors for PeerJ.

\section{Author Contributions}

- Joshua Louis Bonesso conceived and designed the experiments, performed the experiments, analyzed the data, wrote the paper, prepared figures and/or tables, reviewed drafts of the paper.

- William Leggat conceived and designed the experiments, analyzed the data, contributed reagents/materials/analysis tools, wrote the paper, reviewed drafts of the paper.

- Tracy Danielle Ainsworth conceived and designed the experiments, analyzed the data, contributed reagents/materials/analysis tools, wrote the paper, prepared figures and/or tables, reviewed drafts of the paper.

\section{Field Study Permissions}

The following information was supplied relating to field study approvals (i.e., approving body and any reference numbers):

The Great Barrier Reef Marine Park Authority approved this study (permit number G13/36402.1).

\section{Data Availability}

The following information was supplied regarding data availability:

The raw data is supplied as Supplemental Files.

\section{Supplemental Information}

Supplemental information for this article can be found online at http://dx.doi.org/10.7717/ peerj.3719\#supplemental-information. 


\section{REFERENCES}

Agata K, Saito Y, Nakajima E. 2007. Unifying principles of regeneration I: Epimorphosis versus morphallaxix. Development, Growth \& Differentiation 49:73-78 DOI 10.1111/j.1440-169X.2007.00919.x.

Ainsworth TD, Gates RD. 2016. Coral's microbial sentinels. Science 352:1518-1519 DOI 10.1126/science.aad9957.

Ainsworth TD, Heron SF, Ortiz JC, Mumby PJ, Grech A, Ogawa D, Eakin CM, Leggat W. 2016. Climate change disables coral bleaching protection on the Great Barrier Reef. Science 352:338-342 DOI 10.1126/science.aac7125.

Alvarado AS, Tsonis PA. 2006. Bridging the regeneration gap: genetic insights from diverse animal models. Nature Reviews Genetics 7:873-884 DOI 10.1038/nrg1923.

Baird AH, Marshall PA. 2002. Mortality, growth and reproduction in scleractinian corals following bleaching on the Great Barrier Reef. Marine Ecology Progress Series 237:133-141.

Bak RPM. 1983. Neoplasia, regeneration and growth in the reef-building coral Acropora palmata. Marine Biology 77:221-227 DOI 10.1007/BF00395810.

Baker AC, Glynn PW, Riegl B. 2008. Climate change and coral reef bleaching: an ecological assessment of long-term impacts, recovery trends and future outlook. Esturine, Coastal and Shelf Science 80:435-471 DOI 10.1016/j.ecss.2008.09.003.

\section{Bellantuono AJ, Granados-Cifuentes C, Miller DJ, Hoegh-Guldberg O. Rodriguez-} Lanetty M. 2012. Coral thermal tolerance: tuning gene expression to resist thermal stress. PLOS ONE 7:e50685 DOI 10.1371/journal.pone.0050685.

Bosch TC. 2007. Why polyps regenerate and we don't: towards a cellular and molecular framework for Hydra regeneration. Developmental Biology 303:421-433 DOI 10.1016/j.ydbio.2006.12.012.

Böttger A, Alexandrova O. 2007. Programmed cell death in Hydra. Seminars in Cancer Biology 17:134-146 DOI 10.1016/j.semcancer.2006.11.008.

Bou-Abdallah F, Chasteen ND, Lesser MP. 2006. Quenching of superoxide radicals by green fluorescent protein. Biochimica Et Biophysica Acta (BBA)—General Subjects 1760:1690-1695 DOI 10.1016/j.bbagen.2006.08.014.

Brodie J, Fabricius K, De'ath G, Okaji K. 2005. Are increased nutrient inputs responsible for more outbreaks of crown-of-thorns starfish? An appraisal of the evidence. Marine Pollution Bulletin 51:266-278 DOI 10.1016/j.marpolbul.2004.10.035.

Burgess A, Vigneron S, Brioudes E, Labbé J-C, Lorca T, Castro A. 2010. Loss of human Greatwall results in $\mathrm{G} 2$ arrest and multiple mitotic defects due to deregulation of the cyclin B-Cdc2/PP2A balance. Proceedings of the National Academy of Sciences of the United States of America 107:12564-12569 DOI 10.1073/pnas.0914191107.

Burmester EM, Finnerty JR, Kaufman L, Rotjan RD. 2017. Temperature and symbiosis affect lesion recovery in experimentally wounded, facultatively symbiotic temperature corals. Marine Ecology Progress Series 570:87-99. 
Cantin NE, Cohen AL, Karnauskas KB, Tarrant AM, McCorkle DC. 2010. Ocean warming slows coral growth in the central red sea. Science 329:322-325 DOI 10.1126/science.1190182.

Carricart-Ganivet JP, Cabanillas-Teran N, Cruz-Ortega I, Blanchon P. 2012. Sensitivity of calcification to thermal stress varies among genera of massive reef-building corals. PLOS ONE 7:e32859 DOI 10.1371/journal.pone.0032859.

Chera S, Ghila L, Dobretz K, Wenger Y, Bauer C, Buzgariu W, Martinou JC, Galliot B. 2009. Apoptotic cells provide an unexpected source of Wnt3 signaling to drive hydra head regeneration. Developmental Cell 17:279-289 DOI 10.1016/j.devcel.2009.07.014.

Dandan SS, Falter JL, Lowe RJ, McCulloch MT. 2015. Resilience of coral calcification to extreme temperature variations in the Kimberley region, northwest Australia. Coral Reefs 34:1151-1163 DOI 10.1007/s00338-015-1335-6.

D'Angelo C, Smith E, Oswald F, Burt J, Tchernov D, Wiedenmann J. 2012. Locally accelerated growth is part of the innate immune response and repair mechanisms in reef-building corals as detected by green fluorescent protein (GFP)-like pigments. Coral Reefs 31:1045-1056.

De'arth G, Fabriciusa KE, Sweatmana H, Puotinenb M. 2012. The 27-year decline of coral cover on the Great Barrier Reef and its causes. PNAS 44:17995-17999 DOI 10.1073/pnas.1208909109.

De'ath G, Lough JM, Fabricius KE. 2009. Declining coral calcification on the great barrier reef. Science 323:116-119 DOI 10.1126/science.1165283.

DeFilippo L, Burmerster EM, Kaufman L, Rotjan RD. 2016. Patterns of surface lesion recovery in the northern star coral, Astrangia poculata. Journal of Experimental Marine Biology and Ecology 481:15-24.

Denis V, Guillaume MMM, Goutx M, De Palmas S, Debreuil J, Baker AC, Denis V, Guillaume MMM, Goutx M, De Palmas S, Debreuil J, AC Baker AC, Boonstra RK, Bruggemann JH. 2013. Fast growth may impair regeneration capacity in the branching coral acropora muricata. PLOS ONE 8:e72618 DOI 10.1371/journal.pone.0072618.

Desalvo M, Voolstra C, Sunagawa S, Schwarz J, Stillman J, Coffroth M, Szmant AM, Medina M. 2008. Differential gene expression during thermal stress and bleaching in the Caribbean coral Montastraea faveolata. Molecular Ecology 17:3952-3971 DOI 10.1111/j.1365-294X.2008.03879.x.

Dove S. 2004. Scleractinian corals with photoprotective host pigments are hypersensitive to thermal bleaching. Marine Ecology Progress Series 272:99-116 DOI 10.3354/meps272099.

Dove S, Hoegh-Guldberg O, Ranganathan S. 2001. Major colour patterns of reefbuilding corals are due to a family of GFP-like proteins. Coral Reefs 19:197-204 DOI 10.1007/PL00006956.

Dove SG, Lovell C, Fine M, Deckenback J, Hoegh-Guldberg O, Iglesias-Prieto R, Anthony KR. 2008. Host pigments: potential facilitators of photosynthesis in coral 
symbioses. Plant, Cell and Environment 31:1523-1533

DOI 10.1111/j.1365-3040.2008.01852.x.

Edmunds PJ, Gates RD. 2008. Acclimatization in tropical reef corals. Marine Ecology Progress Series 361:307-310 DOI 10.3354/meps07556.

Edmunds PJ, Lenihan HS. 2010. Effect of sub-lethal damage to juvenile colonies of massive Porites spp. under contrasting regimes of temperature and water flow. Marine Biology 157:887-897 DOI 10.1007/s00227-009-1372-1.

Feder ME, Hofmann GE. 1999. Heat-shock proteins, molecular chaperones, and the stress response: evolutionary and ecological physiology. Annual Review of Physiology 61:243-282 DOI 10.1146/annurev.physiol.61.1.243.

Field SF, Bulina MY, Kelmanson IV, Bielawski JP, Matz MV. 2006. Adaptive evolution of multicolored fluorescent proteins in reef-building corals. Journal of Molecular Evolution 62:332-339 DOI 10.1007/s00239-005-0129-9.

Fisher EM, Fauth JE, Hallock-Muller P, Woodley CM. 2007. Lesion regeneration rates in reef-building corals Montastraea spp. As indicators of colony condition. Marine Ecology Progress Series 339:61-71 DOI 10.3354/Meps339061.

Gierer A, Berking S, Bode H, David CN, Flick K, Hansmann G, Schallar H, Trenkner E. 1972. Regeneration of hydra from reaggregated cells. Nature/New Biology 239:98-101.

Goreau TJ, Macfarlane AH. 1990. Reduced growth rate of Montastrea annularis following the 1987-1988 coral-bleaching event. Coral Reefs.

Goss JR, Taffe KM, Kochanek PM, DeKonky ST. 1997. The antioxidant enzymes glutathione peroxidase and catalase increase following traumatic brain injury in the rat. Experimental Neurology 146:291-294 DOI 10.1006/exnr.1997.6515.

Guan L, Zhao J, Scandalios JG. 2000. Cis-elements and trans-factors that regulate expression of the maize Cat1 antioxidant gene in response to $\mathrm{ABA}$ and osmotic stress: $\mathrm{H}_{2} \mathrm{O}_{2}$ is the likely intermediary signalling molecule for the response. The Plant Journal 22:87-95 DOI 10.1046/j.1365-313x.2000.00723.x.

Hall VR. 1997. Interspecific differences in the regeneration of artificial injuries on scleractinian corals. Journal of Experimental Marine Biology and Ecology 212:9-23.

Harrison FW. 1972. The nature and role of the basal pinacoderm of Corvomeyenia carolinensis (Porifera: Spongillidae) a histochemical and developmental study. Hydrobiologia 39:495-508 DOI 10.1007/BF00046742.

Harrison PL, Dubinsky Z, Stambler N. 2011. Coral reefs: an ecosystem in transition. Sexual reproduction of scleractinian corals. Dordrecht: Springer Netherlands, 59-85.

Hill J, Wilkinson C. 2004. Methods for ecological monitoring of coral reefs. Townsville: Australian Institute of Marine Science, 117.

Hoegh-Guldberg O, Mumby PJ, Hooten AJ, Steneck RS, Greenfield P, Gomez E, Harvell CD, Sale PF, Edward Aj, Caldeira K, Knowlton N, Eakin CM, IglesiasPrieto R, Muthiga N, Bradbury RH, Dubi A, Hatziolos ME. 2004. Coral reefs in a century of rapid environmental change. Symbiosis 37:1-31. 
Hoegh-Guldberg O, Mumby P, Hooten A, Steneck R, Greenfield P, Gomez E, Harvell CD, Sale PF, Edwards AJ, Caldiera K, Knowlton N, Eakin CM, IglesiasPrieto R, Muthiga R, Bradbury RH, Dubi A, Hatziolos ME. 2007. Coral reefs under rapid climate change and ocean acidification. Science 318:1737-1742 DOI 10.1126/science.1152509.

Hughes TP, Baird AH, Bellwood DR, Card M, Connolly SR, Folke C, Grosberg R, Hoegh-Guldberg O, Jackson JB, Kleypas J, Lough JM, Marshall P, Nystrom M, Palumbi SR, Pandolfi JM, Rosen B, Roughgarden J. 2003. Climate change, human impacts, and the resilience of coral reefs. Science 301:929-933 DOI 10.1126/science.1085046.

Jokiel PL. 2004. Temperature stress and coral bleaching. In: Coral health and disease. Berlin, Heidelberg: Springer, 401-425.

Jokiel PL, Coles SL. 1977. Effects of temperature on the mortality and growth of Hawaiian reef corals. Marine Biology 43:201-208 DOI 10.1007/BF00402312.

Kaniewska P, Campbell PR, Kline DI, Rodriguez-Lanetty M, Miller DJ, Dove S, Hoegh-Guldberg O. 2012. Major cellular and physiological impacts of ocean acidification on a reef building coral. PLOS ONE 7:1-12

DOI 10.1371/journal.pone.0034659.

Kramarsky-Winter E, Loya Y. 2000. Tissue regeneration in the coral Fungia granulosa: the effect of extrinsic and intrinsic factors. Marine Biology 137:867-873 DOI 10.1007/s002270000416.

Leder JJ, Szmant AM, Swart PK. 1991. The effect of prolonged "bleaching" on skeletal banding and stable isotopic composition in Montastrea annularis. Coral Reefs 10:19-27 DOI 10.1007/BF00301902.

Lough JM, Barnes DJ. 2000. Environmental controls on growth of the massive coral Porites. Journal of Experimnetal Marine Biology and Ecology 245:225-243 DOI 10.1016/S0022-0981(99)00168-9.

Marshall A, Clode P. 2004. Calcification rate and the effect of temperature in a zooxanthellate and an azooxanthellate scleractinian reef coral. Coral Reefs 23:218-224 DOI 10.1007/s00338-004-0369-y.

Matz MV, Marshall NJ, Vorobyev M. 2006. Symposium-in-print: green fluorescent protein and homologs. Photochemistry and Photobiology 82:345-350.

Mayfield AB, Wang L, Tang P, Fan T, Hsiao Y, Tsai C, Chen C. 2011. Assessing the impacts of experimentally elevated temperature on the biological composition and molecular chaperone gene expression of a reef coral. PLOS ONE 6:1-13 DOI 10.1371/journal.pone.0026529.

McCloy RA, Rogers S, Caldon CE, Lorca T, Castro A, Burgess A. 2014. Partial inhibition of Cdk1 in G 2 phase overrides the SAC and decouples mitotic events. Cell Cycle 13:1400-1412 DOI 10.4161/cc.28401.

Meesters EH, Bak RP. 1993. Effects of coral bleaching on tissue regeneration potential and colony survival. Marine Ecology Progress Series 17:189-198.

Meesters H, Bak R. 1994. Effect of coral bleaching on tissue regeneration potential and colony survival. Marine Ecology Progress Series 96:189-198 DOI 10.3354/meps096189. 
Meesters E, Pauchli W, Bak R. 1997. Predicting regeneration of physical damage on a reefbuilding coral by regeneration capacity and lesion shape. Marine Ecology Progress Series 146:91-99 DOI 10.3354/meps146091.

Merle PL, Sabourault C, Richier S, Allemand D, Furla P. 2007. Catalase characterization and implication in bleaching of asymbiotic sea anemone. Free Radical Biology and Medicine 42:236-246 DOI 10.1016/j.freeradbiomed.2006.10.038.

Morgan TH. 1898. Experimental studies of the regeneration of Planaria maculata. Development Genes and Evolution 7:364-397.

Ogawa D, Bobeszko T, Ainsworth T, Leggat W. 2013. The combined effects of temperature and $\mathrm{CO}_{2}$ lead to altered gene expression in Acropora aspera. Coral Reefs 32:895-907 DOI 10.1007/s00338-013-1046-9.

Oren U, Benayahu Y, Loya Y. 1997. Effect of lesion size and shape on regeneration of the Red Sea coral Favia favus. Marine Ecology Progress Series 146:101-107 DOI 10.3354/meps146101.

Palmer CV, Modi CK, Mydlarz LD. 2009. Coral fluorescent proteins as antioxidants. PLOS ONE 4:e7298 DOI 10.1371/journal.pone.0007298.

Palmer CV, Roth MS, Gates RD. 2009. Red fluorescent protein responsible for pigmentation in trematode-infected Porites compressa tissues. The Biological Bulletin 216:68-74 DOI 10.1086/BBLv216n1p68.

Passamaneck YJ, Martindale MQ. 2012. Cell proliferation is necessary for the regeneration of oral structures in the anthozoan cnidarian Nematostella vectensis. BMC Developmental Biology 4:34 DOI 10.1186/1471-213X-12-34.

Pernice M, Dunn SR, Miard T, Dufour S, Dove S, Hoegh-Guldberg O. 2011. Regulation of apoptotic mediators reveals dynamic responses to thermal stress in the reef building coral acropora millepora. PLOS ONE 6:e16095 DOI 10.1371/journal.pone.0016095.

Rodriguez-Lanetty M, Harii S, Hoegh-Guldberg O. 2009. Early molecular responses of coral larvae to hyperthermal stress. Molecular Ecology 18:5101-5114 DOI 10.1111/j.1365-294X.2009.04419.x.

Ross C, Ritson-Williams R, Pierce R, Bullington JB, Henry M, Paul VJ. 2010. Effects of the Florida red tide dinoflagellate, Karenia brevis, on oxidative stress and metamorphosis of larvae of the coral Porites astreoides. Harmful Algae 28:173-179 DOI 10.1007/s00338-012-0956-2.

Roth MS, Deheyn DD. 2013. Effects of cold stress and heat stress on coral fluorescence in reef-building corals. Scientific Reports 3:1-8 DOI 10.1038/srep01421.

Roth MS, Latz MI, Goericke R, Deheyn DD. 2010. Green fluorescent protein regulation in the coral Acropora yongei during photoacclimation. Journal of Experimental Biology 213:3644-3655 DOI 10.1242/jeb.040881.

Salih A, Larkum A, Cox G, Kühl M, Hoegh-Guldberg O. 2000. Fluorescent pigments in corals are photoprotective. Nature 408:850-853 DOI 10.1038/35048564.

Sanchez Alvarado AS. 2000. Regeneration in the metazoans: why does it happen? Bioessays 22:579-590. 
Schlichter D, Weber W, Fricke H. 1985. A chromatophore system in the hermatypic, deep-water coral Leptoseris fragilis (Anthozoa: Hexacorallia). Marine Biology 89:143-147 DOI 10.1007/BF00392885.

Seneca FO, Forêt S, Ball EE, Smith-Keune C, Miller DJ, Van Oppen MJ. 2010. Patterns of gene expression in a scleractinian coral undergoing natural bleaching. Marine Biotechnology 12:594-604 DOI 10.1007/s10126-009-9247-5.

Smith DJ, Suggett DJ, Baker NR. 2005. Is photoinhibition of zooxanthellae photosynthesis the primary cause of thermal bleaching in corals? Global Change Biology 11:1-11 DOI 10.1111/j.1365-2486.2004.00895.x.

Smith-Keune C, Dove S. 2008. Gene expression of a green fluorescent protein homolog as a host-specific biomarker of heat stress within a reef-building coral. Marine Biotechnology 10:166-180 DOI 10.1007/s10126-007-9049-6.

Sørensen J, Dahlgaard J, Loeschcke V. 2001. Genetic variation in thermal tolerance among natural populations of Drosophila buzzatii: down regulation of Hsp70 expression and variation in heat stress resistance traits. Functional Ecology 15:289-296 DOI 10.1046/j.1365-2435.2001.00525.x.

Somorjai IM, Somorjai RL, Garcia-Fernàndez J, Escrivà H. 2012. Vertebratelike regeneration in the invertebrate chordate amphioxus. Proceedings of the National Academy of Sciences of the United States of America 109:517-522 DOI 10.1073/pnas.1100045109.

Stafford-Smith MG. 1993. Sediment-rejection efficiency of 22 species of Australian scleractinian corals. Marine Biology 115:229-243 DOI 10.1007/BF00346340.

Steig EJ, Schneider DP, Rutherford SD, Mann ME, Comiso JC, Shindell DT. 2009. Warming of the Antarctic ice-sheet surface since the 1957 international geophysical year. Nature 457:459-462 DOI 10.1038/nature07669.

Van de Water J, Ainsworth TD, Leggat W, Bourne D, Willis B, Van Oppen MJH. 2015a. The coral immune response facilitates protection against microbes during tissue regeneration. Molecular Ecology 24:3390-3404 DOI 10.1111/mec.13257.

Van de Water J, Leggat W, Bourne D, Van Oppen MJH, Willis B, Ainsworth TD. 2015 b. Elevated seawater temperatures have little impact on the coral immune response following physical damage. Hydrobiologia 759:201-214.

Voolstra CR, Schnetzer J, Peshkin L, Randall CJ, Szmant AM, Medina M. 2009. Effects of temperature on gene expression in embryos of the coral Montastraea faveolata. BMC Genomics 10:627 DOI 10.1186/1471-2164-10-627. 